\title{
Leucine levels in low protein diets for pigs in the initial phase
}

\section{Níveis de leucina em dietas com baixa proteína bruta para suínos na fase inicial}

\author{
Laura Marcela Diaz Huepa ${ }^{1 *}$; Marcelise Regina Fachinello ${ }^{1}$; \\ Lucas Antonio Costa Esteves ${ }^{1}$; Vinicius Ricardo Cambito de Paula ${ }^{2}$; \\ Silvia Leticia Ferreira²; Tiago Junior Pasquetti ${ }^{3}$; Leandro Dalcin Castilha ${ }^{4}$; \\ Ricardo de Souza Vasconcellos ${ }^{4}$; Paulo Cesar Pozza ${ }^{4}$
}

\begin{abstract}
The objective of this study was to evaluate the standardized ileal digestible (SID) leucine levels in low crude protein diets on Performance, backfat thickness, longissimus dorsi depth and biochemical blood parameters of starting pigs. A total of 50 pigs, with initial weight of $11.14 \pm 0.24 \mathrm{~kg}$; were distributed in a randomized blocks design with five treatments $(1.10 ; 1.25 ; 1.40 ; 1.55$ and $1.70 \%$ SID leucine), five replicates and two animals per experimental unit, comprised for a barrow and a gilt. The feed conversion ratio $(\mathrm{FCR})$ reduced $(\mathrm{P}=0.018)$ due to the increasing SID leucine levels, without affecting other growth performance parameters (final weight, average daily feed intake, average daily gain, backfat thickness, longissimus dorsi depth and lean meat percentage). There was a quadratic effect for plasma triglyceride $(\mathrm{P}=0.049)$ and plasma urea $(\mathrm{P}=0.001)$. The optimal SID leucine levels obtained for triglycerides and urea were $1.16 \%$ and $1.24 \%$, respectively, by associating the quadratic model with the Linear Response Plateu. Low crude protein diets with SID leucine levels up to $1.70 \%$ improved the feed conversion with desired urea and triglycerides concentration in blood plasma achieved at $1.16 \%$ and $1.24 \%$, respectively. Key words: Antagonism. Blood parameters. Branched chain amino acids. Performance.
\end{abstract}

\section{Resumo}

O objetivo do presente trabalho foi o de avaliar níveis de leucina digestível em dietas com baixa proteína bruta sobre o desempenho, espessura de toucinho, profundidade do músculo longissimus dorsi parâmetros sanguíneos de suínos na fase inicial. Foram utilizados 50 suínos mestiços (Landrace $\mathrm{x}$ Large white $\mathrm{x}$ Pietrain), com peso inicial de 11,14 $\pm 0,24 \mathrm{~kg}$; distribuídos em um delineamento experimental de blocos casualizados, com cinco tratamentos $(1,10 ; 1,25 ; 1,40 ; 1,55$ e $1,70 \%$ de leucina digestível), cinco repetições e dois animais por unidade experimental, sendo um macho castrado e uma fêmea. A conversão alimentar reduziu $(\mathrm{P}=0,018)$ em função do aumento dos níveis de leucina digestível, sem influenciar os demais parâmetros de desempenho (peso final, consumo diário de ração, ganho de peso

1 Discentes, Curso de Doutorado, Programa de Pós-Graduação em Zootecnia, Universidade Estadual de Maringá, UEM, Maringá, PR, Brasil. E-mail: lauramvz28@hotmail.com; lise_faqui@hotmail.com; lucasantonio_esteves@hotmail.com

2 Discentes, Curso de Mestrado, Programa de Pós-Graduação em Zootecnia, Faculdade de Medicina Veterinária e Zootecnia, Universidade Estadual Paulista "Júlio de Mesquita Filho", UNESP, Campus de Botucatu, Botucatu, SP, Brasil. E-mail: leticiacalif@gmail.com; viniciusrcp@gmail.com

3 Prof. Dr., Departamento de Zootecnia, Universidade Estadual de Mato Grosso do Sul, UEMS, Aquidauana, PR, Brasil. E-mail: pasquettizoo@yahoo.com.br

4 Profs. Drs., Departamento de Zootecnia, UEM, Maringá, PR, Brasil. E-mail: 1dcastilha@uem.br; rsvasconcellos@uem.br; pcpozza@uem.br

* Author for correspondence 
diário, espessura de toucinho, profundidade de lombo e porcentagem de carne magra). Com relação às variáveis plasmáticas foi observado efeito quadrático para a concentração de triglicerídeos $(\mathrm{P}=0,049)$ e ureia $(\mathrm{P}=0,001)$ em que associado ao platô do modelo Linear Response Platô (LRP) observou-se que o nível ótimo de leucina digestível para triglicerídeos e ureia foi de $1,16 \%$ e $1,24 \%$, respectivamente. A menor concentração de ureia plasmática foi obtida ao nível de $1,24 \%$ de leucina digestível. Dietas com baixa proteína bruta e níveis de até $1,70 \%$ de leucina digestível melhoram a conversão alimentar dos suínos na fase inicial com a melhor concentração de ureia e triglicerídeos no plasma sanguíneo de $1,16 \%$ e $1,24 \%$, respectivamente.

Palavras-chave: Aminoácidos de cadeia ramificada. Antagonismo. Desempenho. Parâmetros sanguíneos.

\section{Introduction}

Industrial amino acids (AA) used in pig diets aims to meet its needs and provide a better diet formulation, decreasing nitrogen excretion and optimizes the growth performance. Branched Chain Amino Acids (BCAA) are consider essential AA, comprising leucine, valine and isoleucine, sharing the same enzymes for their oxidative transamination and decarboxylation's (SHIMOMURA; HARRIS, 2006). Leucine appears to antagonize other BCAA, since the excess reduces the concentrations of valine, isoleucine and its keto acids in plasma and tissues (TANNOUS et al., 1966; LANGER; FULLER, 2000). Different researches developed with rats (TORRES et al., 1995), poultry (CALVERT et al., 1982; FARRAN et al., 2002) and pigs (LANGER et al., 2000; WILTAFSKY et al., 2010) reported negative responses in average daily gain (ADG) and a reduced feed intake in response an excess of dietary leucine.

Although leucine excess may be detrimental to growth performance, it also may affect cellular processes by stimulating and increasing protein synthesis through the activation of mTOR, and reducing the losses of endogenous nitrogen through the inhibition of protein degradation through its $\beta$-hydroxybutyrate, synthetized from $\alpha$-ketoisocaproate (MANJARREZ et al., 2015).

This paradox characterizes the need for researches that quantifies the requirement of standardized ileal digestible (SID) leucine for pigs, a challenge to the performance of these studies is the difficulty of inducing a leucine deficiency in the diet due to its high content in the ingredients (ROSTAGNO et al., 2011). The main source of protein used in conventional diets (soybean meal) has low levels of valine $(1.93 \%)$ and isoleucine $(1.88 \%)$ when compared to leucine $(3.11 \%)$ (ROSTAGNO et al., 2011). Thus, conventional diets generally have an excess of SID leucine in relation to the requirements, which may affect growth parameters performance. Most of the studies were directed to the leucine antagonism with the other BCAA (LANGER et al., 2000; WILTAFSKY et al., 2010; GLOAGUEN et al., 2012). This fact can also be associated with the greater importance given to valine and isoleucine, since they are the fifth and sixth limiting AA, respectively, in diets based on corn and soybean meal for pigs (LANGER; FULLER, 2000).

Furthermore, in conventional diets with a low crude protein $(\mathrm{CP})$ content the inclusion of synthetic amino acids is required so that the diet formulation meets the ideal protein concept, thus nutrients are offered in exact quantities (NRC, 2012). The fifth and sixth amino acid limiting pigs may be necessarily included.

The knowledge of the pig responses to different levels of SID leucine becomes important as a way of quantifying the requirements of this AA. Thus, the objective of this study was to evaluate SID leucine levels in low crude protein diets for starting pigs. 


\section{Material and Methods}

The experiment was carried out in the Swine Sector of the Experimental Farm of Iguatemi, which belonging to the Universidade Estadual de Maringá (UEM). The experiment was approved by the UEM Animal Care and Use (Protocol n. 8538100616).

Fifty crossbred pigs (Landrace x Large White $\mathrm{x}$ Pietrain), 25 barrows and 25 gilts, averaging $11.14 \pm 0.240 \mathrm{~kg}$ of initial weight, were distributed in a randomized complete blocks design with five treatments, five replicates and two animals per experimental unit (one barrow and one gilt).
Treatments consisted of five SID leucine levels $(1.10,1.25,1.40,1.55$ and $1.70 \%)$. Following the recommendations of the nutritional requirements of the NRC (2012) for starting pigs (11 - $25 \mathrm{~kg}$ ). The experimental diets were formulated with corn, soybean meal, minerals, vitamins, amino acids and additives (Table 1). The CP content was reduced $(15.16 \%)$ in relation to that suggested by Rostagno et al. (2011) (19.50\%), but the nitrogen level proposed by NRC (2012) was used. L-leucine was added to diets at the expense of the inert to meet SID leucine levels. Glutamic acid was used in order to keep the same nitrogen content in all experimental diets.

Table 1. Chemical and energetic composition (as fed basis) of diets containing different levels of SID leucine (Leu) for pigs in the initial phase $(15-30 \mathrm{~kg})^{1}$.

\begin{tabular}{|c|c|c|c|c|c|}
\hline \multirow{2}{*}{ Ingredients $\left(\mathrm{g} \mathrm{Kg}^{-1}\right)$} & \multicolumn{5}{|c|}{ SID leucine (\%) } \\
\hline & 1.10 & 1.25 & 1.40 & 1.55 & 1.70 \\
\hline Corn & 773.06 & 773.06 & 773.06 & 773.06 & 773.06 \\
\hline Soybean meal & 146.26 & 146.26 & 146.26 & 146.26 & 146.26 \\
\hline Limestone & 8.19 & 8.19 & 8.19 & 8.19 & 8.19 \\
\hline Dicalcium Phosphate & 13.59 & 13.59 & 13.59 & 13.59 & 13.59 \\
\hline Sodium Bicarbonate & 6.72 & 6.72 & 6.72 & 6.72 & 6.72 \\
\hline Soybean oil & 19.74 & 19.36 & 18.98 & 18.60 & 18.58 \\
\hline Glutamic acid & 7.68 & 5.76 & 3.84 & 1.92 & 0.000 \\
\hline L-Lysine $\mathrm{HCl}$ & 8.94 & 8.94 & 8.94 & 8.94 & 8.94 \\
\hline L-Threonine & 3.34 & 3.34 & 3.34 & 3.34 & 3.34 \\
\hline DL-Methionine & 2.96 & 2.96 & 2.96 & 2.96 & 2.96 \\
\hline L-Tryptophan & 0.08 & 0.08 & 0.08 & 0.08 & 0.08 \\
\hline L-Valine & 2.63 & 2.63 & 2.63 & 2.63 & 2.63 \\
\hline L-Isoleucine & 1.78 & 1.78 & 1.78 & 1.78 & 1.78 \\
\hline L-Leucine & 0.06 & 1.65 & 3.24 & 4.83 & 6.42 \\
\hline L-Histidine & 0.99 & 0.99 & 0.99 & 0.99 & 0.99 \\
\hline L-Phenylalanine & 1.59 & 1.59 & 1.59 & 1.59 & 1.59 \\
\hline Clean sand & 0.59 & 1.31 & 2.02 & 2.73 & 3.08 \\
\hline Vit + Min supplement ${ }^{2}$ & 1.50 & 1.50 & 1.50 & 1.50 & 1.50 \\
\hline Antioxidant ${ }^{3}$ & 0.10 & 0.10 & 0.10 & 0.10 & 0.10 \\
\hline Antibiotic $^{4}$ & 0.20 & 0.20 & 0.20 & 0.20 & 0.20 \\
\hline Total & 1000 & 1000 & 1000 & 1000 & 1000 \\
\hline
\end{tabular}


Continuation...

\begin{tabular}{lccccc}
\hline \multirow{2}{*}{ Ingredients $\left(\mathrm{g} \mathrm{Kg}^{-1}\right)$} & \multicolumn{5}{c}{ SID leucine $(\%)$} \\
\cline { 2 - 6 } & 1.10 & 1.25 & 1.40 & 1.55 & 1.70 \\
\hline Calculated Composition $\left(\mathrm{g} \mathrm{Kg}^{-1}\right)$ & 14.00 & 14.00 & 14.00 & 14.00 & 14.00 \\
\hline Metabolizable Energy $\left(\mathrm{M} \mathrm{k} \mathrm{kg}^{-1}\right)$ & 2.42 & 2.42 & 2.42 & 2.42 & 2.42 \\
Total nitrogen (\%) & 7.00 & 7.00 & 7.00 & 7.00 & 7.00 \\
Calcium & 3.30 & 3.30 & 3.30 & 3.30 & 3.30 \\
Available phosphorus & 2.00 & 2.00 & 2.00 & 2.00 & 2.00 \\
Sodium & 4.94 & 4.94 & 4.94 & 4.94 & 4.94 \\
Potassium & 2.26 & 2.26 & 2.26 & 2.26 & 2.26 \\
Chloride & 12.30 & 12.30 & 12.30 & 12.30 & 12.30 \\
SID Lys & 6.80 & 6.80 & 6.80 & 6.80 & 6.80 \\
SID Met + Cyst & 7.30 & 7.30 & 7.30 & 7.30 & 7.30 \\
SID Threonine & 2.00 & 2.00 & 2.00 & 2.00 & 2.00 \\
SID Tryptophan & 7.51 & 7.51 & 7.51 & 7.51 & 7.51 \\
SID Arginine & 7.80 & 7.80 & 7.80 & 7.80 & 7.80 \\
SID Valine & 11.00 & 12.50 & 14.00 & 15.50 & 17.00 \\
SID Leucine & 6.30 & 6.30 & 6.30 & 6.30 & 6.30 \\
SID Isoleucine & 4.74 & 4.74 & 4.74 & 4.74 & 4.74 \\
SID Methionine & 4.20 & 4.20 & 4.20 & 4.20 & 4.20 \\
SID Histidine & 9.15 & 9.15 & 9.15 & 9.15 & 9.15 \\
SID Phen + Tyr & 7.20 & 7.20 & 7.20 & 7.20 & 7.20 \\
SID Phenylalanine & & & & \\
\hline
\end{tabular}

${ }^{1-}$ SID: standardized ileal digestible. ${ }^{2-}$ Provide per kilogram of diet: (nutrition levels $\mathrm{kg}^{-1}$ of diet): Vit. A - 3000 UI; Vit. D3 - 600 UI; Vit. E - 6 UI; Vit. B1 - 0,588 mg; Vit. B2 - 1,2795 mg; Vit. B6 - 0,594 mg; Vit. B12 - 7,9995 mcg; Vit. K3 - 0,7275 mg; Calcium pantothenate - 4,749 mg; Niacin - 12,7995 mg; Folic acid - 0,159 mg; Biotin - 0,039 mg; Antioxidant - $3 \mathrm{mg}$; Zn - 0,03 g; Fe 0,0225 g; Mn - 0,0156 mg; Cu - 3,6 mg; I - 0,2475 mg; Co - 0,0405 mg; Selênio - 0,09 mg; Veiculo Q.S.P. - 1,5 g. ${ }^{3-B H T ; ~}{ }^{4-T y l a n . ~}$

The amino acid compositions of corn and soybean meal were determined at EVONIK Industries and the true ileal digestibility coefficients proposed by Rostagno et al. (2011), were applied to the analyzed data.

Animals were housed in a nursery, with suspended pens $\left(1.32 \mathrm{~m}^{2}\right)$ and a partly leaked floor, equipped with feeders, located in the front of the pen, and a nipple type drinker in the back.

Animals were weighed at the beginning and at the end of the experiment to determine the average daily gain (ADG) and the diets were weighed whenever provided to the animals to determine the average daily feed intake (ADFI) and feed conversion ratio (FCR).
At the end of the experiment, the animals were submitted to the evaluation of backfat thickness (BT) and longissimus dorsi depth (LD) through ultrasound equipment Aloka ${ }^{\circledR}$ SSD 500 Vet, coupled to a $7.5 \mathrm{~cm}$ and $3.5 \mathrm{MHz}$ probe. The $\mathrm{P} 2$ site, located at the last rib of the chest, was determined at $6 \mathrm{~cm}$ from the midline, where the site was cleaned and the images were kept. Afterwards, the measurements of BT and LD were performed by using Image Pro Plus ${ }^{\circledR}$ software.

The lean meat percentage (LMP) was determined by using an equation to estimate this parameter (in vivo), as follows: $\mathrm{Y}=60.69798-0.89211 \mathrm{~S}$ + 0.10560M; (VÍTEK et al., 2008); where Y = estimated percentage of lean meat; $\mathrm{S}=\mathrm{BT}(\mathrm{cm})$; 
$\mathrm{M}=$ depth of the muscle at the measurement point.

After a 6-hour fast, cranial vena cava blood samples were collected and stored in tubes containing EDTA anticoagulant (CAI et al., 1994) to determine triglyceride, urea, total protein, total cholesterol and creatinine in the blood plasma. For glucose determination, the blood samples were collected into glass tubes containing sodium fluoride.

Blood samples were centrifuged at 3.000 RPM during 15 minutes and samples used for glucose determination were centrifuged during 30 minutes to obtain the blood plasma. Then $3 \mathrm{~mL}$ of blood plasma were transferred to Eppendorf ${ }^{\circledR}$ type tubes.

The biochemical analyzes were performed by using enzymatic colorimetric Kits (Laborclin ${ }^{\circledR}$ ), following the operational procedures described in the Kits, and the concentration of each blood biochemical component were determined by absorbance reading (BIOPLUS ${ }^{\circledR} 2000$ Spectrophotometer).
Data regarding performance, $\mathrm{BT}, \mathrm{LD}, \mathrm{LMP}$ and blood parameters were submitted to analysis of variance. The degrees of freedom related to SID leucine levels were deployed in orthogonal polynomials for regression fitting. The initial weight was used as a covariate for the performance parameters. Was used to assess the effect of performance, BT, LD, LMP and blood parameters $\mathrm{x}$ leucine levels. Data were also adjusted by the quadratic model associated and LRP model (SAKOMURA; ROSTAGNO, 2016). Statistical analysis were performed by the Statistical and Genetic Analysis System - SAEG ${ }^{\circledR}$ (2009).

\section{Results and Discussion}

The FCR reduced $(\mathrm{P}=0.018)$ as SID leucine increased in the diet, indicating a growth performance enhancement. The final weight (FW), ADFI, ADG, LD, BT and LMP were similar $(\mathrm{P}>0.05)$ between the SID leucine levels evaluated (Table 2).

Table 2. Performance (kg), Backfat thickness (BT) $\left(\mathrm{cm}^{2}\right)$, longissimus dorsi depth (LD) (cm) and lean meat percentage (LMP) of pigs in the initial phase fed low crude protein diets with different levels of SID leucine.

\begin{tabular}{lllllllll}
\hline & \multicolumn{3}{l}{ SID leucine $(\%)$} & \multicolumn{3}{c}{$P$ - value } \\
\cline { 2 - 8 } Item $^{1}$ & 1.10 & 1.25 & 1.40 & 1.55 & 1.70 & SEM & Linear & Quadratic \\
\hline IW & 11.04 & 11.17 & 11.21 & 11.21 & 11.09 & 0.107 & 0.7077 & 0.2011 \\
FW & 23.81 & 24.85 & 24.95 & 25.44 & 24.86 & 0.590 & 0.1912 & 0.2799 \\
ADFI & 0.916 & 0.974 & 0.916 & 0.951 & 0.946 & 0.027 & 0.7834 & 0.9588 \\
ADG & 0.437 & 0.455 & 0.450 & 0.487 & 0.473 & 0.019 & 0.1182 & 0.8481 \\
FCR $^{2}$ & 2.11 & 2.14 & 2.04 & 1.96 & 2.01 & 0.072 & 0.0188 & 0.6039 \\
BT & 0.453 & 0.435 & 0.473 & 0.422 & 0.491 & 0.023 & 0.2587 & 0.2604 \\
LD & 2.353 & 2.378 & 2.380 & 2.290 & 2.276 & 0.070 & 0.2620 & 0.1899 \\
LMP & 60.54 & 60.56 & 60.52 & 60.56 & 60.49 & 0.021 & 0.1488 & 0.1312 \\
\hline
\end{tabular}

${ }^{1-} \mathrm{IW}=$ Initial weight; $\mathrm{FW}=$ Final weight; $\mathrm{ADFI}=$ Average daily feed intake; $\mathrm{ADG}=$ Average daily gain; $\mathrm{FCR}=\mathrm{Feed}$ conversion ratio; ${ }^{2-} \mathrm{Y}=2.48874-0.331127 \mathrm{X}\left(\mathrm{R}^{2}=0.46\right)$. SEM: Standard Error of Mean.

Piglets fed diets containing $1.97 \%$ and $3.75 \%$ SID leucine showed a decrease in the ADFI compared to pigs receiving a control diet containing $1.09 \%$ SID leucine (WESSELS et al., 2016). According to the authors, this feed intake reduction may be due to the competition in the uptake of amino acids, specifically in brain tissues, since the membrane transporters are the same for BCAAs and tryptophan, reducing 
the tryptophan concentration crossing this cephalic barrier and acting with the serotonin production, acting in the appetite regulation. In this sense, the SID leucine levels evaluated in this study should have not provided the same effects mentioned above, since the ADFI was not affected $(\mathrm{P}>0.05)$. However, SID leucine levels evaluated (1.10 $1.70 \%$ ) were lower than those studied by Wessels et al. (2016), indicating that commonly SID leucine levels found in commercial starting pig diets do not affect the feed intake.

Excess leucine (1.95\%) associated with valine deficiency reduces the dietary protein utilization and the first response of the animal is the reduction in feed intake and, therefore, reduction in growth rate (GLOAGUEN et al., 2012). The studied SID leucine levels (1.10 to $1.70 \%$ ) associated with the SID valine meeting pigs requirements may explain the same feed intake $(\mathrm{P}>0.05)$ obtained (Table 2$)$. With feed intake similar to that recommended by the NRC (2012) with a requirement of $1.23 \%$ SID leucine when compared to Rostagno et al. (2011) whit a requirement of $1.081 \%$ of SID leucine.

However, an opposite trend was observed by Yin et al. (2010) supplementing L-leucine (1.88\%) in diets with $16.9 \%$ of $\mathrm{CP}$ for weaning piglets, reporting that the ADG was better compared with piglets receiving the control diet $(1.36 \%$ SID leucine), without affecting the ADFI, concluding that chronic L-leucine supplementation promotes the growth of muscle tissue, liver and gut.

As SID leucine levels increased (1.10; 1.25; $1.40 ; 1.55$ and $1.70 \%$ ) FCR improved (Table 2). An opposite result was found by Wessels et al. (2016) who observed that FCR was not influenced by excess SID leucine in the piglet diets. In the same way, Wiltafsky et al. (2010), increased SID leucine in piglet diets, from 8 to $25 \mathrm{~kg}(1.29 ; 1.81 ; 2.09$; 2.35 and $2.41 \%$ ) and observed increased in FCR as dietary SID leucine levels increased. These results demonstrate that levels higher than those used in the present study $(1.70 \%)$ may reduce FCR. The effects of SID leucine on FCR may be related to the expression of the cationic AA transporter $\left(\mathrm{b}^{0,+}\right)$, which is responsible for the absorption of leucine and lysine in the gut (GARCIA et al., 2015).

A worse FCR was observed by Gloaguen et al. (2013) evaluating SID leucine:lysine ratios (70; $78 ; 86 ; 94 ; 102$ e $130 \%$ ) for 10 to $15 \mathrm{~kg}$ piglets, concluding that leucine excess (102 and 130\%), as well as leucine deficiency (10\% less SID leucine in the basal diet) negatively affected the productive efficiency of the piglets, also indicating that the SID leucine:lysine ratio of $102 \%$ is not necessary for protein deposition, but may be an important factor in the competition of AAs, which may increase catabolism, especially of valine and isoleucine.

The addition of L-leucine in low-protein diets may have adverse effects on animal performance, reducing feed intake and increasing FCR, even if results are not significant (ERWAN et al., 2009). However, a high variability in these results between the researches is observed, being the adverse effects usually observed when using high levels of SID leucine in low CP diets.

Leucine also stimulates the activity of mTOR, which is responsible for protein metabolism in muscle tissue (DRUMMOND et al., 2009). Many studies have demonstrated a high activity of proteins associated protein synthesis of piglets submitted to leucine infusions, after the first 24 hours of live (ESCOBAR et al., 2005; BOUTRY et al., 2013). Similarly, Torrazza et al. (2010) observed that leucine supplementation in piglet diets with low CP stimulated protein synthesis in the LD, gastrocnemius and masseter muscles, and increased the anabolic capacity of organs such as the heart, jejunum, kidneys and pancreas.

Although leucine supplementation promotes muscle tissue growth (YIN et al., 2010), the levels of SID leucine evaluated in this study did not promote the same effects as mentioned above, since the LD and LMP were not affected $(\mathrm{P}>0.05)$. 
Regarding the plasma parameters (Table 3), no differences $(\mathrm{P}>0.05)$ were observed for glucose, total proteins, total cholesterol and creatinine. However, triglycerides $(\mathrm{P}=0.0497)$ and urea $(\mathrm{P}=0.0014)$ were affected by SID leucine, fitting a quadratic model associated with the LRP model showing a lower triglyceride concentration $\left(26.44 \mathrm{mg} \mathrm{dL}^{-1}\right)$ at $1.16 \%$ SID leucine (Figure 1a) and the best plasma urea concentration (Figure 1b) was achieved at $1.24 \%$ SID leucine (13.54 $\left.\mathrm{mg} \mathrm{dL}^{-1}\right)$.

Table 3. Plasma levels of glucose, triglycerides, urea, total proteins, total cholesterol (mg dL-1) and creatinine $\left(\mathrm{U} \mathrm{L}^{-1}\right)$ of pigs in the initial phase fed low crude protein diets with different levels of SID leucine.

\begin{tabular}{lllllllll}
\hline \multirow{2}{*}{ Item } & \multicolumn{3}{l}{ SID leucine (\%) } & \multicolumn{3}{c}{ P - value } \\
\cline { 2 - 9 } & 1.10 & 1.25 & 1.40 & 1.55 & 1.70 & Stand. Erro & Linear & Quadratic \\
\hline Glucose & 75.33 & 74.83 & 76.33 & 75.00 & 74.33 & 0.333 & 0.8096 & 0.7242 \\
Triglyceride $^{1}$ & 28.50 & 24.50 & 21.80 & 26.88 & 26.00 & 1.136 & 0.6446 & 0.0497 \\
Urea $^{2}$ & 17.50 & 12.00 & 12.13 & 14.00 & 14.50 & 1.000 & 0.2061 & 0.0014 \\
Total proteins & 5.93 & 5.28 & 5.70 & 5.59 & 5.46 & 0.110 & 0.4014 & 0.5531 \\
Total cholesterol & 70.32 & 60.10 & 66.88 & 69.50 & 71.12 & 2.002 & 0.1942 & 0.0589 \\
Creatinine & 1.24 & 1.30 & 1.26 & 1.27 & 1.19 & 0.018 & 0.6663 & 0.5473 \\
\hline
\end{tabular}

${ }^{1-} \mathrm{Y}=113.248-126.417 \mathrm{X}+44.5238 \mathrm{X}^{2}\left(\mathrm{R}^{2}=0.57\right) ;{ }^{2} \mathrm{Y}=101.338-124.871 \mathrm{X}+43.6444 \mathrm{X}^{2}\left(\mathrm{R}^{2}=0.75\right)$.

In the process of carbon catabolism of AAs, there are specific routes for each one. Metabolic intermediates such as Acetyl-CoA and AcetoacetylCoA form fatty acids, which are derived from the metabolism of ketogenic AA, such as leucine, responsible for the formation of ketone bodies such as energy and cholesterol stores (NELSON; COX,
2011), but increasing SID leucine levels decreased the plasma concentration of triglycerides at the level of $1.16 \%$ SID leucine (Table 3), it was observed that there was no excess of triglycerides and consequently no deposition of fat although leucine stimulated adipogenesis and lipogenesis (MELNIK, 2012).

Figure 1. Triglyceride (a) and urea (b) in pig plasma (11 to $25 \mathrm{~kg}$ ) as a function of different levels of SID leucine in the diet.

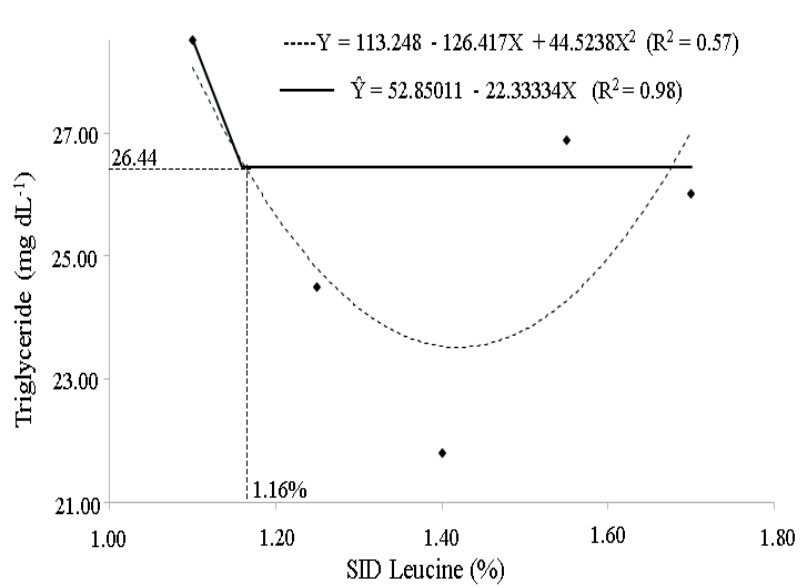

(a)

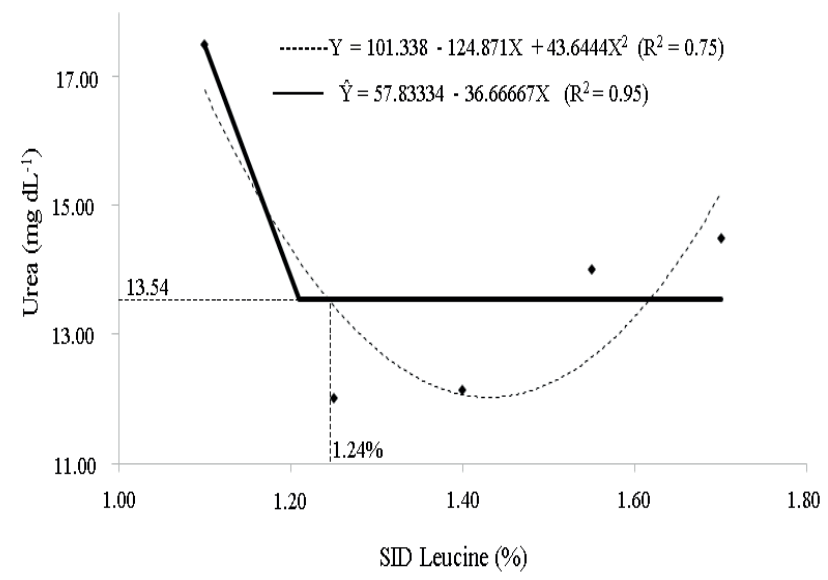

(b) 
Studying the BCAA effects on triglycerides accumulation in the tissues of obese rats, Arakawa et al. (2011) observed that rats fed a diet with a high concentration of BCAA $(2 \%)$ reduced the triglycerides levels in skeletal muscle and liver, concluding that this reduction was induced by BCAA, avoiding an increase in the concentration of triglycerides because its excess interferes with the uptake of glucose by the GLUT4 intracellular transporter, stimulated by plasma insulin.

Contrary to the findings of the present study, Duan et al. (2016) and Li et al. (2016) did not observe changes in plasma triglyceride concentrations evaluating diets containing 17 and $20 \%$ CP with different levels of BCAA for starting piglets, concluding that diets containing $1.44 \%$ and $2.35 \%$ SID leucine increased the concentration of intramuscular fat in the femoral biceps.

SID leucine levels did not affected ADFI and ADG, but improving FCR (Table 2) seems to indicate a better leucine use not affecting the other BCAA. However, it is know that urea is the main product of protein catabolism and when amino acids are not reused for the synthesis of new amino acids, or nitrogen products, the amino groups are directed to this final excretion product (NELSON; COX, 2011). This effect may had occurred below the $1.24 \%$ SID leucine level. The results of the present research suggest that SID leucine levels above $1.24 \%$ may have contributed to increasing BCAA catabolism and other AA, increasing the urea concentration in the blood plasma, indicating a high AA degradation. This was also found by Ren et al. (2015) reporting a reduction in plasma urea concentration $\left(98.22 \mathrm{nMol} \mathrm{mL}^{-1}\right)$ in piglets fed low CP diets (17.85\%) supplemented with BCAA (1.38\% SID leucine), indicating that in addition to the $\mathrm{CP}$ reduction the $\mathrm{BCAA}$ supplementation further reduces plasma urea concentration because it allows a better balance between the limiting AA in the diet.

On the other hand, the leucine excess in the diet is related to a greater degradation of valine and isoleucine, due to competition for the enzyme dehydrogenase of branched-chain $\alpha$-ketoacid (HARRIS et al., 2001). This response was observed by Gatnau et al. (1995), attributing the reduction in plasma concentrations of valine and isoleucine to a leucine excess and its metabolites in piglet diets. Thus, plasma urea concentration may be a good indicator of the amino acid degradation process. According to Reeds et al. (1987), metabolic changes of excess leucine in the diet can be study by measuring urea synthesis and by leucine, isoleucine and valine turnover (HOLECEK, 2013).

Leucine, in addition to changes in plasma concentration of urea and other AA, such as valine and isoleucine(MACOTELA et al., 2011), stimulates the synthesis of muscle protein (PASIAKOS; McCLUNG, 2011). Although the level of 1.24\% SID leucine provided the lowest catabolism (lower nitrogen excretion), no significant effect was observed for $\mathrm{LD}(\mathrm{P}>0.05)$. Similar results were found by Madeira et al. (2014) who did not observe any effect of leucine supplementation in low CP diets on performance or carcass traits.

The optimal SID leucine level (1.24\%) obtained for plasma urea concentration, determined by the association of the quadratic model and LRP model, are close to that recommended by the NRC (2012) for 10 to $25 \mathrm{~kg}$ pigs (1.23\% SID leucine). The use of industrial AA allows a formulation of diets with low CP content (LORDELO et al., 2008), as in the present study $(15.16 \% \mathrm{CP})$, taking into account the nutritional requirements of the essential $\mathrm{AA}$ and allowing an increase in the efficiency of nitrogen use in the diet. However, according to Mansilla et al. (2015), the CP affects the concentration of endogenous nitrogen, which is an important for non-essential AA synthesis.

Thus, emphasizing the importance of CP content in body nitrogen deposition, Langer et al. (2000) indicated that $15 \% \mathrm{CP}$ diets and leucine excess increased the catabolism of valine or isoleucine, reducing the nitrogen utilization of the diet and 
possibly affecting the deposition of muscle protein. However, Langer and Fuller (2000) did not observe changes in the body nitrogen concentrations of females fed diets containing 15\% CP and excess leucine, concluding that even with high BCAAs levels in the diet, the concentration and retention of body nitrogen were not affected. Likewise, LD and LMP were not affected $(\mathrm{P}>0.05)$ by SID leucine levels, indicating that the retention of body nitrogen was not affected by SID leucine levels evaluated in the present study.

\section{Conclusions}

Low crude protein diets with SID leucine levels up to $1.70 \%$ improved the feed conversion with desired urea and triglycerides concentration in blood plasma achieved at $1.16 \%$ and $1.24 \%$, respectively.

\section{Acknowledgements}

Universidade Estadual de Maringá and Programa de Estudantes - Convênio de Pós-graduação (PECPG)

\section{References}

ARAKAWA, M.; MASAKI, T.; NISHIMURA, J.; MASATAKA, S.; YOSHIMATSU, H. The effects of branched-chain amino acid granules on the accumulation of tissue triglycerides and uncoupling proteins in dietinduced obese mice. Endocrine Journal, Oita, v. 58, n. 3 , p. 161-170, 2011.

BOUTRY, C.; EL-KADI, S. W.; SURYAWAN, A.; WHEATLEY, S. M.; ORELLANA, R. A.; KIMBALL, S. R.; NGUYEN, H. V.; DAVIS, T. A. Leucine pulses enhance skeletal muscle protein synthesis during continuous feeding in neonatal pigs. American Journal of Physiology, Endocrynology and Metabolism, Hershey, v. 305, n. 5, p. E620-E631, 2013.

CAI, Y.; ZIMMERMAN, D. R.; EWAN, R. C. Diurnal variation in concentrations of plasma urea nitrogen and amino acids in pigs given free access to feed or fed twice daily. The Journal of Nutrition, Bethesda, v. 124, n. 7, p. 1088-1093, 1994.
CALVERT, C. C.; KLASING, K. C.; AUSTIC, R. E. Involvement of food intake and amino acid catabolism in the branched-chain amino acid antagonism in chicks. The Journal of Nutrition, Bethesda, v. 112, n. 4, p. 627635, 1982.

DRUMMOND, M. J.; DREYER, H. C.; CHRISTOPHER, S.; FRY, C. S.; GLYNN, E. L.; RASMUSSEN, B. B. Nutritional and contractile regulation of human skeletal muscle protein synthesis and mTORC1 signaling. Journal of Applied Physiology, Galvestone, v. 106, n. 6, p. 1374-1384, 2009.

DUAN, Y.; DUAN, Y.; LI, F.; LI, Y.; GUO, Q.; JI, Y.; TAN, B.; LI, T.; YIN, Y. Effects of supplementation with branched-chain amino acids to low-protein diets on expression of genes related to lipid metabolism in skeletal muscle of growing pigs. Amino Acids, Hunan, v. 48, n. 9, p. 2131-2144, 2016.

ERWAN, E.; ALIMON, A. R.; SAZILI, A. Q.; YAAKUB, H.; HILMI, M. Effect of L-Leucine supplementation on growth performance and carcass characteristics of grower-broiler chickens fed low protein diets. American Journal of Animal and Veterinary Sciences, Riau, v. 4. n. 4, p. 95-100, 2009.

ESCOBAR, J.; FRANK, J. W.; SURYAWAN, A.; NGUYEN, H. V.; KIMBALL, S. R.; JEFFERSON, L. S.; DAVIS, T. A. Physiological rise in plasma leucine stimulates muscle protein synthesis in neonatal pigs by enhancing translation initiation factor activation. American Journal of Physiology, Endocrynology and Metabolism, Hersey, v. 288, n. 5, p. E914-E921, 2005.

FARRAN, M. T.; BARBOUR, E. K.; ASHKARIAN, V. M. Effect of excess leucine in low protein diet on ketosis in 3-week-old male broiler chicks fed different levels of isoleucine and valine. Animal Feed Science and Technology, Beirut, v. 103, n. 1-4, p. 171-176, 2002.

GARCIA, H.; MORALES, A.; ARAIZAL, A.; HTOO, J. K.; Cervantes, M. Gene expression, serum amino acid levels, and growth performance of pigs fed dietary leucine and lysine at different ratios. Genetics and Molecular Research, Hanau, v. 14, n. 1, p. 1589-1601, 2015.

GATNAU, R.; NISSEN, L.; ZIRNMERMAN, D. R.; WANNEMUEHLERT, M.; EWAN, C. Effects of excess dietary leucine and leucine catabolites on growth and immune responses in weanling pigs. The Journal of Animal Science, Champaign, v. 73, n. 1, p. 159-165, 1995.

GLOAGUEN, M.; LE FLOC'H, N.; CORRENT, E.; PRIMOT, Y.; VAN MILGEN, J. Providing a diet deficient in valine but with excess leucine results in a rapid decrease in feed intake and modifies the postprandial 
plasma amino acid and $\alpha$-keto acid concentrations in pigs. The Journal of Animal Science, Champaign, v. 90, n. 9, p. 3135-3142, 2012.

GLOAGUEN, M.; LE FLOC'H, N.; PRIMOT, Y.; CORRENT, E.; VAN MILGEN, J. Response of piglets to the standardized ileal digestible isoleucine, histidine and leucine supply in cereal-soybean meal-based diets. Animal, Rennes, v. 7, n. 6, p. 901-908, 2013.

HARRIS, R. A.; KOBAYASHI, R.; MURAKAMI, T.; SHIMOMURA, Y. Regulation of branched-chain $\alpha$-keto acid dehydrogenase kinase expression in rat liver. The Journal of Nutrition, Bethesda, v. 131, n. 3, p. 841-845, 2001.

HOLECEK, M. Branched-chain amino acids and ammonia metabolism in liver disease: therapeutic implications. Nutrition, Hradec Králové, v. 29, n. 10, p. 1186-1191, 2013.

LANGER, S.; FULLER, M. F. Interactions among the branched-chain amino acids and their effects on methionine utilization in growing pigs: effects on nitrogen retention and amino acid utilization. The British Journal of Nutrition, London, v. 83, n. 1, p. 43-48, 2000.

LANGER, S.; SCISLOWSKI, P. W. D.; BROWN, D. S.; DEWEY, P.; FULLER, M. F. Interactions among the branched-chain amino acids and their effects on methionine utilization in growing pigs: effects on plasma amino- and keto-acid concentrations and branched-chain keto-acid dehydrogenase activity. The British Journal of Nutrition, London, v. 83, n. 1, p. 49-58, 2000.

LI, Y.; WEI, H.; LI, F.; CHEN, S.; DUAN, Y.; GUO, Q.; LIU, Y.; YIN, Y. Supplementation of branched-chain amino acids in protein-restricted diets modulates the expression levels of amino acid transporters and energy metabolism associated regulators in the adipose tissue of growing pigs. Animal Nutrition, Changsha, v. 2, n. 1, p. 24-32, 2016.

LORDELO, M. M.; GASPAR, A. M.; LE BELLEGO, L.; FREIRE, J. P. B. Isoleucine and valine supplementation of a low-protein corn-wheat-soybean meal-based diet for piglets: Growth performance and nitrogen balance. The Journal of Animal Science, Lisboa, v. 86, n. 11, p. 29362941, 2008.

MACOTELA, Y.; BRICE, E.; BANG, A. M.; ESPINOZA, D. O.; BOUCHER, J.; BEEBE, K.; GALL, W.; KAHN, R. Dietary leucine - an environmental modifier of insulin resistance acting on multiple levels of metabolism. Plos One, San Francisco, v. 6, n. 6, p. 1-13, 2011.

MADEIRA, M. S.; ALFAIA, C. M.; COSTA, P.; LOPES, P. A.; LEMOS, J. P. C.; BESSA, R. J. B.; PRATES,
J. A. M. The combination of arginine and leucine supplementation of reduced crude protein diets for boars increases eating quality of pork. The Journal of Animal Science, Champaign, v. 92, n. x, p. 2030-2040, 2014.

MANJARREZ, R. M. O.; TORRES-VACA, M.; GONZALES-GALLEGO, J.; ORDONES-ALVEAR, I. El $\beta$-hidroxi- $\beta$-metilbutirato (HMB) como suplemento nutricional (I): metabolismo y toxicidad. Nutrición Hospitalaria, León, v. 31, n. 2, p. 590-596, 2015.

MANSILLA, W. D.; COLUMBUS, D. A.; HTOO, J. K.; CORNELIS, F. M. de L. Nitrogen absorbed from the large intestine increases whole-body nitrogen retention in pigs fed a diet deficient in dispensable amino acid nitrogen. The Journal of Nutrition, Hanau, v. 145, n. 6, 1163-1169, 2015.

MELNIK, B. C. Leucine signaling in the pathogenesis of type 2 diabetes and obesity. World Journal of Diabetes, Osnabrück, v. 3, n. 3, 38-53, 2012.

NATIONAL RESEARCH COUNCIL - NRC. Nutrients requirement of swine. $11^{\text {th }}$ ed. Washington: National Academic Press, 2012. 210 p.

NELSON, D. L.; COX, M. M. Princípios de bioquímica de Lehninger. 5. ed. São Paulo: SARVIER, 2011. 682 p.

PASIAKOS, M.; MCCLUNG, J. P. Supplemental dietary leucine and the skeletal muscle anabolic response to essential amino acids. Nutrition Reviews, Natick, v. 69, n. 9, p. 550-557, 2011.

REEDS, P. J.; FULLER, M. F.; DADENHEAD, A.; HAY, S. M. Urea synthesis and leucine turnover in growing pigs: changes during $2 \mathrm{~d}$ following the addition of carbohydrate or fat to the diet. The British Journal of Nutrition, London, v. 58. n. 2, p. 301-311, 1987.

REN, M.; ZHANG, H.; ZENG, X. F.; LIU, H.; QIAO, $Y$. Branched-chain amino acids are beneficial to maintain growth performance and intestinal immune-related function in weaned piglets fed protein restricted diet. The Journal of Animal Science, Beijing, v. 28, n. 12, p. 17421750, 2015.

ROSTAGNO, H. S.; ALBINO, L. F. T.; DONZELE, J. L.; GOMES, P. C.; OLIVEIRA, R. F.; LOPES, D. C.; FERREIRA, A. S.; BARRETO, S. L. T.; EUCLIDES, R. F. Tabelas brasileiras para aves e suínos: composição de alimentos e exigências nutricionais. 3. ed. Viçosa, MG: UFV, 2011. 200 p.

SAKOMURA, N. K.; ROSTAGNO, H. S. Métodos de pesquisa em nutrição de monogástricos. 2. ed. Campinas: Fundação de Apoio à Pesquisa e Extensão, Funep, 2016. $145 \mathrm{p}$. 
SHIMOMURA, Y.; HARRIS, R. A. Metabolism and physiological function of branched-chain amino acids: discussion of session 1. The Journal of Nutrition, Bethesda, v. 136, n. 1, p. 232-233, 2006.

SAEG ${ }^{\circledR}$ SAEG: sistema para análises estatísticas, versão 9.1. Viçosa: Universidade Federal de Viçosa, 2009.

TANNOUS, R. I.; QUINTON, R. R.; HARPER, A. E. Effect of Leucine-lsoleucine antagonism on the amino acid pattern of plasma and tissues of the rat. Archives of Biochemistry and Biophysics, Cambrigde, v. 113, n. 2, p. 356-351, 1966.

TORRAZZA, R. M.; SURYAWAN, A.; GAZZANEO, M. C.; ORELLANA, R. A.; FRANK, J. W. NGUYEN, H. V.; FIOROTTO, M. L. EL-KADI, S.; DAVIS, T. A. Leucine supplementation of a low-protein meal increases skeletal muscle and visceral tissue protein synthesis in neonatal pigs by stimulating mTor-dependent translation initiation. The Journal of Nutrition, Bethesda, v. 140, n. 12, p. 2145-2152, 2010.

TORRES, N.; TOMAR, A.; HARPER, A. E. Leucine affects the metabolism of valine by isolated perfused rat hearts: relation to branched-chain amino acid antagonism. The Journal of Nutrition, Madison, v. 125, n. 7, p. 188493, 1995.
VÍTEK, M.; PULKRÁBEK, J.; VALIŠ, L.; DAVID, L.; WOLF, J. Improvement of accuracy in the estimation of lean meat content in pig carcasses. Czech Journal of Animal Science, Prague-Uhřiněves, v. 53, n. 5, p. 204211, 2008.

WESSELS, A. G.; KLUGE, H.; HIRCHE, F.; KIOWSKI, A.; SCHUTKOWSKI, A.; CORRENT, E.; BARTELT, J.; KONIG, B.; STANGL, I. High leucine diets stimulate cerebral branched-chain amino acid degradation and modify serotonin and ketone body concentrations in a pig model. Plos One, San Francisco, v. 11, n. 3, p. 1-15, 2016.

WILTAFSKY, M. K.; PFAFFL, M. W.; ROTH, F. X. The effects of branched-chain amino acid interactions on growth performance, blood metabolites, enzyme kinetics and transcriptomics in weaned pigs. British Journal of Nutrition, London, v. 103, n. 7, p. 964-976, 2010.

YIN, Y.; YAO, K.; LIU, Z.; GONG, M.; RUAN, Z.; DENG, D.; TAN, B.; LIU, Z.; WU, G. Supplementing L-leucine to a low-protein diet increases tissue protein synthesis in weanling pigs. Amino Acids, Nanchang, v. 39, n. 5, p. 1477-1486, 2010. 
